DOI 10. 18307/2022. 0124

(C) 2022 by Journal of Lake Sciences

\title{
三峡工程运用后荆江河段崩岸时空分布及其对河床调整的影响”
}

\author{
夏军强 ${ }^{1 * *}$, 刘 釒 $^{1}$, 邓珊珊 ${ }^{1}$, 周美蓉 ${ }^{1}$, 李志威 ${ }^{1}$, 彭玉明 ${ }^{2}$ \\ (1:武汉大学水资源与水电工程科学国家重点实验室,武汉 430072) \\ (2:长江水利委员会水文局荆江水文水资源勘测局,荆州 434020)
}

\begin{abstract}
摘 要: 三峡工程运用后长江中游荆江河段河床持续冲刷, 局部河段崩岸频发, 影响河道内悬沙输移与河床形态调整. 本 研究采用实测长程河道地形及固定断面地形资料, 确定了 2002-2018 年荆江河段的主要崩岸区域, 估算了崩岸土体的泥 沙总量,进而定量分析了河岸崩退对河床调整的影响. 计算结果表明: 荆江段累计河岸崩退体积约为 2.0 亿 $\mathrm{m}^{3}$, 约占该河 段总冲刷量的 $17.5 \%$; 腊林洲及北门口河段累计崩岸体积与累计水流冲刷强度呈较好的幂函数关系 $\left(R^{2}=0.95,0.97\right)$; 荆 江段崩岸土体泥沙总量为 2.7 亿 $\mathrm{t}$, 其中枝城一监利河段崩岸土体总量为 1.67 亿 $\mathrm{t}$ 约占该河段沿程泥沙补给总量的 $30.7 \%$, 因此崩岸土体对悬沙沿程恢复有重要贡献; 河岸持续崩退过程中, 崩岸河段内的断面形态趋于宽浅, 护岸工程修 建后则明显趋于窄深, 因此河道崩岸过程在一定程度上减缓了河床的冲深下切程度.
\end{abstract}

关键词 : 河道崩岸;崩岸土体体积;断面形态;河床调整;荆江河段;三峡工程

\section{Temporal and spatial distribution of bank retreat in the Jingjiang reach of the Yangtze Riv- er after the Three Gorges Project operation and its influence on channel adjustment*}

\author{
Xia Junqiang ${ }^{1 * *}$, Liu Xin ${ }^{1}$, Deng Shanshan ${ }^{1}$, Zhou Meirong $^{1}$, Li Zhiwei ${ }^{1} \&$ Peng Yuming ${ }^{2}$ \\ (1: State Key Laboratory of Water Resources and Hydropower Engineering Science, Wuhan University, Wuhan 430072, P.R. \\ China) \\ (2: Jingjiang Bureau of Hydrology and Water Resources Survey, Changjiang Water Resources Commission, Jingzhou 434020, \\ P.R.China)
}

\begin{abstract}
After the operation of the Three Gorges Project, the Jingjiang reach underwent remarkable channel degradation, and bank retreat occurred frequently in local sub-reaches, which affected the transport of suspended sediment and the adjustments of channel geometry. The measured fluvial topographic maps and cross-sectional profiles during the period of 2002-2018 were adopted to determine the main zones and volumes of bank erosion, and the effect of bank retreat was then analyzed quantitatively on the channel adjustments of the Jingjiang reach. Calculated results show that: the cumulative volume of bank erosion in the Jingjiang reach was about $2.0 \times 10^{8} \mathrm{~m}^{3}$ during the period of 2002-2018, which accounted for $17.5 \%$ of the cumulative channel scour volume $\left(11.4 \times 10^{8} \mathrm{~m}^{3}\right)$. Empirical relationships were developed between cumulative bank erosion volume and fluvial erosion intensity during flood seasons in the Lalinzhou and Beimenkou sub-reaches, with the determination coefficients of 0.95 and 0.97 respectively. In addition, the total sediment amount from bank erosion in the Jingjiang reach was around $2.7 \times 10^{8} \mathrm{t}$, and the total amount in the reach between Zhicheng and Jianli was $1.67 \times 10^{8} \mathrm{t}$, accounting for about $30.7 \%$ of the total amount of sediment supplied from the channel. Therefore, bank retreat played an important role in the suspended sediment transport, especially for the recovery of fine sand along the channel. Finally, cross-sectional profiles tended to be wide and shallow during the stage of continuous bank retreat, while they became narrow and deep after the construction of bank revetment engineering. Therefore, bank retreat can reduce the undercutting of the riverbed to a certain extent in the Jingiang reach.
\end{abstract}

Keywords: Bank erosion; soil volume from bank erosion; cross-sectional geometry; channel adjustments; Jingjiang reach; Three Gorges Project

* 2021-04-23 收稿;2021-06-28 收修改稿.

国家自然科学基金项目 (51725902, U2040215，52009095)和中国博士后科学基金项目(2020M682476)联合资助.

** 通信作者;E-mail:xiajq@ whu.edu.cn. 
冲积河流上修建水库后, 不仅改变了进人下游河道的水沙条件,同时会引起坝下游河流的再造床过程. 尤其在水库运用初期, 坝下游河流将发生自上而下的普遍冲刷, 使河床形态发生显著调整, 主要包括床面冲 深与河岸崩退 ${ }^{[1-4]}$. 三峡工程运用后 (2003-2018 年), 进人长江中游河道的水量略有减少, 但沙量减少幅度 高达 70\% 90\%, 使得坝下游河流发生长距离、长时间的河床冲刷, 长江中游河道已累计冲刷 24.1 亿 $\mathrm{m}^{3}$ (平 滩河槽). 在河床持续冲刷过程中, 岸坡变陡、主流顶冲或深泓贴岸导致局部河段崩岸现象频发. 据不完全统 计, 三峡工程运用后中下游干流河道共发生崩岸险情 937 处, 累计崩岸长度约 $701 \mathrm{~km}$, 尤以荆江河段最为严 重 $^{[5-6]}$. 长江中游河道崩岸, 不仅影响防洪安全及河势稳定, 还严重威胁沿江经济社会发展和群众生命财产 安全 ${ }^{[3]}$. 但以往多研究荆江河段的崩岸机理与数值模拟方法, 很少考虑较长时段内的崩岸土体总量及其对 河床调整的影响. 因此如何估算三峡工程运用后荆江河段的崩岸土体总量, 定量分析崩岸对该河段河床调 整的影响,对全面掌握荆江段的河床演变规律具有重要意义.

估算某一特定时段内河道崩岸土体的体积,通常需要采用固定断面地形、河道地形图、高精度的航测或 遥感影像数据 ${ }^{[7-8]}$. 三峡工程运用后, 长江中游宜昌一湖口段共设有固定断面 578 个, 平均间距约 $1.7 \mathrm{~km}^{[9]}$. 通常采用断面地形数据, 直接计算平滩河宽的变化或河岸崩退速率, 用于近似表示单位河长的崩岸体积. 夏 军强等 ${ }^{[7]}$ 采用固定断面地形资料, 分析了三峡工程运用后荆江河段的崩岸过程及特点: $2002-2015$ 年约有 $21 \%$ 断面存在明显的崩岸现象, 且近 74\% 的崩岸断面位于下荆江. 可采用不同时期的河道地形图估算某一 研究河段的崩岸土体总量. 例如许昫心和师长兴 ${ }^{[10]}$ 采用不同年份汉江丹江水库下游游荡段的河道地形图, 计算了该河段的年均河岸土体冲刷量为 0.127 亿 $\mathrm{t} / \mathrm{a}(1968-1983$ 年), 略大于同期的床面冲刷量 0.106 亿 $\mathrm{t} / \mathrm{a}$. 随着现代测量技术的发展, 崩岸测量逐渐采用地面摄影、航空摄影以及遥感影像与数字地形高程模型 (DEM) 相结合的方法, 这些方法能较为精确地捕捉岸线变形, 直接计算两个测次间的崩岸土体总量 ${ }^{[11-14]}$. Payne 等 ${ }^{[8]}$ 将高精度的遥感影像资料与 DEM 结合, 确定了美国 Colville 河沿主河道分布 4 个悬崖点的崩退 速率及土体体积, 计算得到这 4 个点的平均崩退速率为 $0.9 \sim 1.5 \mathrm{~m} / \mathrm{a}\left(1955-2015\right.$ 年). Williams 等 $^{[12]}$ 将航 空摄影照片与基于 LiDAR 技术的 DEM 结合, 用于自动测量崩岸土体的体积. Azuma ${ }^{[13]}$ 采用数字摄影经纬仪 精确测量了日本 Uji 河一段 $250 \mathrm{~m}$ 长岸线的崩退过程, 9 个月内该段河岸的崩塌体积达 $3000 \mathrm{~m}^{3}$. Leyland 等 ${ }^{[14]}$ 采用移动激光扫描仪 (MLS) 与多波速测深仪 (MBES), 结合多普勒流速剖面仪 (ADCP), 详细观测了㴮 公河一长约 $2 \mathrm{~km}$ 河段汗期的崩岸及水沙输移过程, 发现该河段 2014 年汛期平均崩退速率为 $50.8 \mathrm{~m} / \mathrm{a}$.

河岸崩退是坝下游河床变形过程中的一个重要方面, 它与河床的纵向变形同样重要, 因此需要研究河 道崩岸与河床调整之间的定量关系, 包括崩岸土体总量占河床冲淤量的比例、典型断面或河段崩退速率与 来水来沙条件之间的定量关系. 三门峡水库蓄水拦沙运用期间, 黄河下游平均每年冲刷泥沙 5.58 亿 $\mathrm{t}$, 细沙 占 $43.3 \%$, 其中有近 $35 \%$ 的细沙来源于滩地的崩退. 长时间的清水冲刷造成大量滩地坍塌, 同时使花园口河 段的河槽宽度增加近 $1 \mathrm{~km}^{[15]}$. 小浪底水库运用后 (1999-2013 年), 黄河下游游荡段持续冲刷, 花园口一夹 河滩河段平滩河宽增加了 $666 \mathrm{~m}$, 累计滩岸崩退土体体积为 2.1 亿 $\mathrm{m}^{3}$, 约占同期该河段河床冲刷量的 $37 \%{ }^{[16]}$. 许畑心和师长兴 ${ }^{[10]}$ 定量分析了丹江口水库下游游荡段崩岸与河床调整的复杂关系,包括崩岸与主 槽下切展宽及洲滩演变的关系. 已有研究表明, 坝下游平滩河宽的调整与来水来沙条件密切相关 ${ }^{[17-18]}$. 夏军 强等 ${ }^{[7]}$ 定量分析了河岸土体组成与分布、来水来沙条件等因素对荆江河段崩岸过程的影响, 发现来水来沙 条件的影响占主导地位, 并建立了典型断面平滩河宽与前期水沙条件之间的经验关系. Spiekermann 等 $^{\left[{ }^{[18}\right]}$ 分 析了新西兰 Kaipara 流域内 5 个 $3 \sim 14 \mathrm{~km}$ 长河段的崩岸过程, 发现多年年均的崩退速率与平均洪峰流量之 间存在简单的线性关系.

本文采用荆江河段不同时段的河道地形图,2002-2018 年历年汛后 171 个固定断面地形, 以及近期该 河段内各水文站的实测水沙等资料, 计算荆江崩岸土体总量, 并定量分析崩岸对河床调整的影响. 首先基于 不同时段的岸线变化确定荆江段的崩岸位置及范围,计算整个荆江河段内崩岸土体的体积; 然后建立典型 局部河段的累积崩岸土体体积与来水来沙条件的函数关系; 最后分析崩岸对河床调整的具体影响, 包括崩 岸土体对河道输沙量的贡献,以及崩岸对河床形态调整的影响. 


\section{1 研究区域与数据来源}

\section{1 研究区域}

荆江河段上起枝城, 下迄城陵矶, 全长 $347.2 \mathrm{~km}$, 其间以藕池口为界, 分为上、下荆江(图 1 ). 上荆江属 于典型的微弯分汉型河道, 沿程弯道相对平顺且洲滩密布. 江口以上河道两岸主要为低山丘陵; 江口以下河 岸为上部黏性土层和下部沙土层组成的二元结构, 且在大部分河岸黏性土层厚度超过沙土层厚度 ${ }^{[3]}$. 近期 上荆江崩岸区域主要集中在腊林洲、青安二圣洲及南五洲等局部河段. 下荆江属于典型的弯曲型河道, 主要 由石首、调关、监利及七弓岭等 10 个弯曲段组成. 下荆江河岸也为二元结构, 不同之处在于上部黏性土层较 薄, 仅有 1 3 m, 而下部沙土层较厚且大于上部黏性土层厚度, 故河岸抗冲性较差 ${ }^{[19]}$.

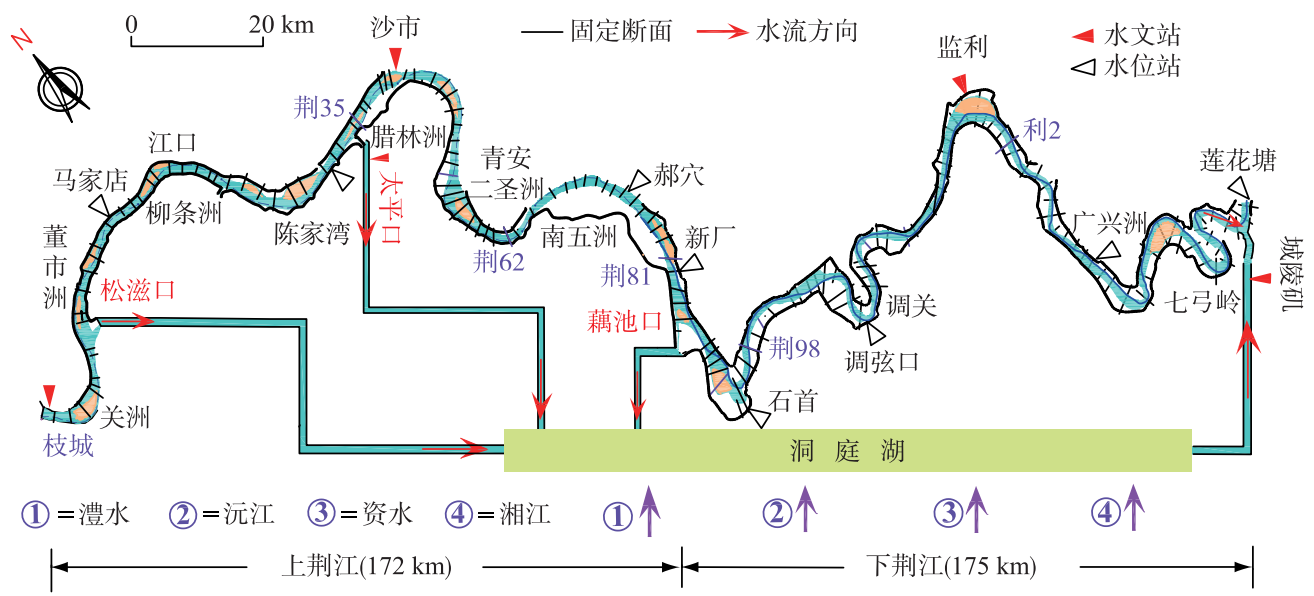

图 1 长江荆江段河道示意图

Fig.1 Sketch map of the Jingjiang reach in the middle Yangtze River

荆江河段水沙主要源于长江上游干流及各级人汇支流, 其间通过松滋口、太平口及藕池口分流分沙至 洞庭湖. 若忽略三口分流的影响, 枝城站可视为荆江河段来水来沙的控制站. 枝城站 1991-2018 年的水沙 资料表明: 三峡工程运用前 ( 1991-2002 年)、运用后 (2003-2018 年) 枝城站多年平均流量分别为 4351.9× $10^{8}$ 和 $4182.4 \times 10^{8} \mathrm{~m}^{3}$, 后者减少约 $3.9 \%$; 多年平均输沙量分别为 $3.9 \times 10^{8}$ 和 $0.4 \times 10^{8} \mathrm{t}$, 后者减少约 $89.7 \%$ (图 2a). 此外, 2002-2018 年荆江河段平滩河槽累计冲刷量为 $11.4 \times 10^{8} \mathrm{~m}^{3}$, 其中上、下荆江分别占 $60 \%$ 和 $40 \%$ ( 图 2b).
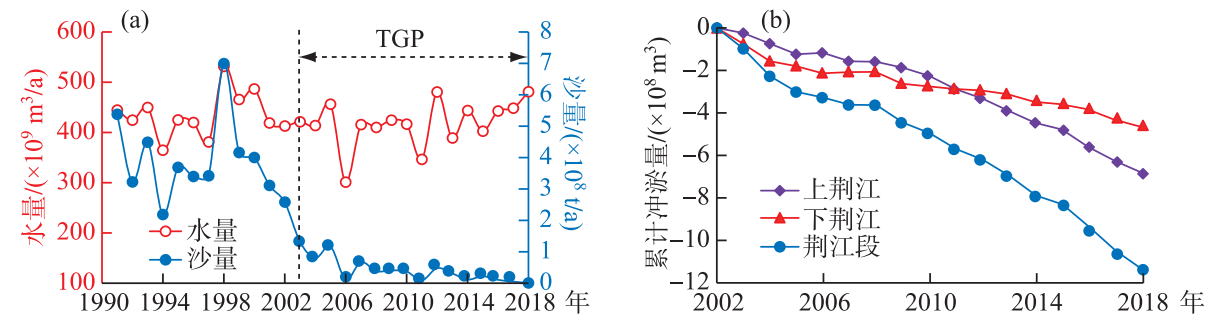

图 2 荆江河段来水来沙条件 ( a ) 及河床冲淤过程 $(\mathrm{b})$

Fig.2 Temporal variations in the flow and sediment regime (a) and cumulative channel evolution volume (b)

\section{2 数据来源}

崩岸土体总量估算首先需要计算崩退体积, 主要包括崩退面积及河岸高度的确定. 采用长程河道地形 图确定崩退面积, 但该地形图无法确定岸顶及坡脚位置, 故河岸高度的确定需要收集断面地形资料. 本研究 
采用的地形及水沙资料均源于长江水利委员会水文局,包括若干测次的长程河道地形资料 (包含水下地形 及岸上地形), 测量精度为 $1: 10000$; 每年汛后测量的固定断面地形资料, 测量精度为 $1: 5000$; 以及枝城、沙市 等水文站的流量、含沙量等水文资料. 局部河段崩岸土体总量等于崩退体积与土体干密度之乘积 (折算成实 际沙量), 故还需收集主要崩岸区域的土体特性资料. 本研究采用的河岸土体特性数据主要源于研究团队多 年来通过野外查勘与室内土工试验获取的资料,包括荆 34 、荆 98 等几十个断面 ${ }^{[3]}$.

\section{2 崩岸土体总量估算方法}

荆江段固定断面地形每年汛后测量 1 次, 长程河道地形 $2 \sim 5$ 年测量 1 次. 此处提出采用长程河道地形、 固定断面地形及土体特性资料确定崩岸位置并估算崩岸土体总量的方法, 具体包括崩岸面积、河岸高度的 确定方法以及崩岸土体泥沙总量估算方法. 结合长程河道地形及固定断面地形只能反映初始及最终的河岸 形态,无法区分河岸后退是河床横向累积变形还是崩塌引起的,此处暂不将两者分开统计.

\section{1 崩岸面积确定方法}

计算崩岸土体体积, 首先需要在平面上确定研究河段内主要崩岸区域及其对应的崩岸面积. 此处采用 长程河道地形图结合固定断面地形, 确定河岸崩退面积. 测量精度为 $1: 10000$ 的长程河道地形图是目前长 江中下游精度较高的地形数据, 测量范围通常包括水下地形和岸上地形, 一般含有测量控制点、水边线、等 高线、基础地理标记等图层 ${ }^{[20]}$. 考虑到河道地形图中沿程岸 (坎) 线实测点残缺不全, 而水边线的数据相对 完整且可靠, 此处结合水边线及固定断面地形确定崩岸区域及崩退面积. 具体计算步骤如下: (1) 将两个不 同年份包含水边线、测量控制点等图层的长程河道地形套绘到同一地形图中; (2) 对比图中不同年份水边线 的相对位置,初步确定主要崩岸区域,同时套绘崩岸区域内不同年份的固定断面地形进行验证; (3) 将不同 测次两条水边线包围的崩岸区域面积视为河岸崩退面积. 应当指出, 水边线并不能完全代表岸线,但荆江段 的河道地形图中注明了测量当天的河道水位,对于坡度较缓的河岸需要结合崩岸河段内固定断面地形对崩 退面积按比例修正. 经核对, 2002 与 2018 年水下地形图中不同崩岸位置最大水位差为 $1.7 \mathrm{~m}$, 最小为 $0.1 \mathrm{~m}$, 均值为 $0.69 \mathrm{~m}$. 因此采用水边线确定崩退面积具有一定的可靠性. 采用上述方法确定了沙市河段及石首弯 道内 3 个主要崩岸位置 (腊林洲、向家洲及北门口河段), 对应的崩退面积分别为 584377 、384218 和 2175453 $\mathrm{m}^{2}$ (图 3).
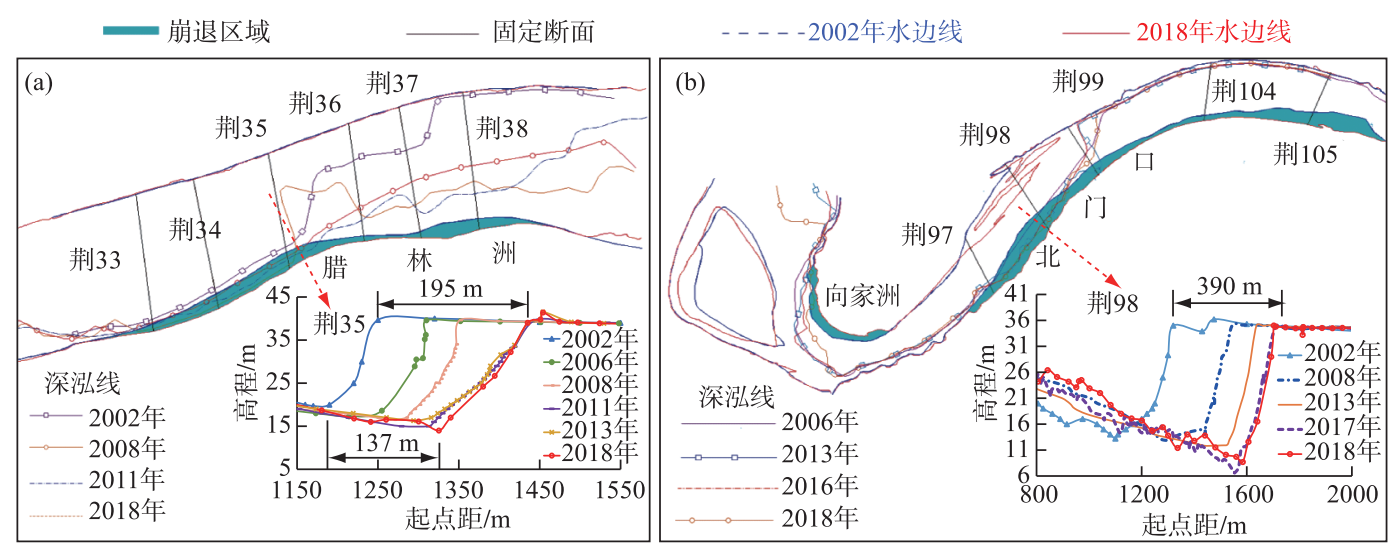

图 3 基于长程河道地形图与固定断面地形确定的崩岸位置及崩退面积: 腊林洲河段 ( a ) ; 北门口河段 (b)

Fig.3 Determination of zone and area of bank erosion based on the fluvial topographic maps and cross-sectional profiles in the sub-reaches of Lalinzhou (a) and Beimenkou (b)

\section{2 河岸高度确定方法}

要计算崩岸土体体积还需确定河岸高度, 本研究通过点绘崩岸区域内固定断面地形, 确定不同位置的 崩退类型及河岸高度. 荆江河段横断面形态多为不规则 “ $U$ ”型、偏 “ $V$ ”型和 “ $W$ ”型, 其中 “ $U$ ”型断面多发生 
平行崩退, 偏“V”型断面多发生坡脚冲刷并逐步向“U”型断面发展, 而“W”型断面则两种类型均有发生. 采 用固定断面地形资料确定河岸高度,具体原则包括: (1) 将滩唇视为河岸的顶部界面 (图 4 中 A 点);(2) 对 于“U”型断面,将近岸深槽最低点视为河岸的底部界面 (图 4a 中 B 点); (3) 对于偏“V”型或“W”型断面, 可 将崩岸后岸坡上斜率突变的位置 (图 4b 中 C 点) 或者岸坡与枯水位的交点 (图 4c 中 D 点) 视为河岸底部界 面. 顶部界面与底部界面的高程之差即为河岸高度. 此处选用的枯水位是 2002-2018 年各固定断面 5000 $\mathrm{m}^{3} / \mathrm{s}$ 流量下水位的均值. 根据上述原则, 图 4 中荆 81 、荆 62 以及利 2 断面的河岸高度分别为 $21.2 、 10.8$ 和 $9.1 \mathrm{~m}$.
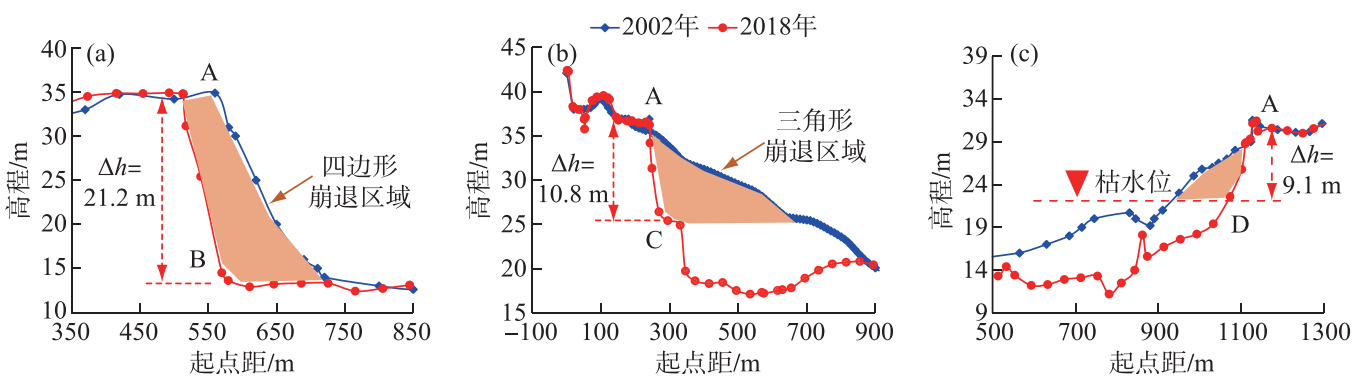

图 4 不同岸坡形态下河岸高度的确定方法:荆 81(a) ; 荆 62(b) ; 利 2(c)

Fig.4 Methods to determine the bank height for different bank profile types at sections of Jing81 (a), Jing62 (b) and Li2 (c)

\section{3 崩岸土体泥沙总量估算方法}

在确定崩岸面积及河岸高度的基础上, 将崩岸区域内所有固定断面河岸高度的均值视为一个崩岸点的 平均河岸高度,采用体积公式计算崩退土体的体积. 若崩退区域的平面形态为四边形 (图 4a), 则采用四棱 柱的体积公式 (式 1); 若崩退区域的平面形态呈三角形 (图 4b), 则采用三棱柱的体积公式(式 2); 若两种类 型均存在,则分段计算:

$$
\begin{gathered}
V=\Delta A \cdot \Delta h \\
V=(\Delta A \cdot \Delta h) / 2
\end{gathered}
$$

式中, $V$ 为崩退土体体积, $\mathrm{m}^{3} ; \Delta A$ 为崩退区域的平面面积, $\mathrm{m}^{2} ; \Delta h$ 为崩退区域的平均河岸高度, $\mathrm{m}$. 结合不同 区域的崩退体积及土体干密度数据, 可计算对应区域崩退土体的泥沙总量, 即:

$$
M=V \cdot \rho_{\mathrm{d}}
$$

式中, $M$ 为崩岸土体的泥沙总量, $\mathrm{kg} ; \rho_{\mathrm{d}}$ 为土体干密度, $\mathrm{kg} / \mathrm{m}^{3}$. 应当说明, 由于收集的土体干密度资料有限, 此处将同一崩岸位置的土体干密度视为常数. 此外, 部分崩岸区域已实施了岸线守护工程, 但此处统计的崩 退体积不包括守护工程的土石方量.

\section{3 荆江段崩岸土体总量计算结果}

此处首先给出上、下荆江典型断面的崩退过程, 进而给出荆江河段崩岸的沿程分布特点以及主要崩岸 位置崩岸土体总量的统计结果, 在此基础上分析崩岸土体体积与来水来沙条件之间的函数关系.

\section{1 典型断面崩退过程}

荆江河段二元结构河岸由上部黏性土层及下部沙土层组成, 河岸崩塌方式主要有平面滑动、圆弧滑动 及绕轴崩塌 ${ }^{[3]}$. 受河势调整的影响, 不同位置崩岸原因及过程略有不同. 断面形态的调整可直观地反映河岸 崩退速率及崩塌形态, 故此处选取上荆江腊林洲、下荆江北门口两个河段, 分析典型断面河岸崩退的具体过 程及原因.

3.1.1 上荆江典型断面崩岸过程 三峡工程运用后, 上荆江总体河势较为稳定, 但在主流顶冲或深泓贴岸部 位以及洲滩调整相对剧烈的局部河段, 仍存在崩岸现象, 主要崩岸位置有火箭洲、腊林洲及青安二圣洲等. 图 2a 给出了腊林洲 2002 以来部分年份岸线、深泓线的具体位置. 腊林洲河段深弜线一直紧靠右岸, 水流不 
断淘刷近岸坡脚, 导致河岸持续崩退, 崩退面积约为 $58.4 \times 10^{4} \mathrm{~m}^{2}$. 同时为更直观地反映河岸崩退过程, 图 2a 给出了荆 35 断面右岸岸坡形态的变化过程,2002-2011 年该断面右岸坡脚持续冲刷内靠,横向摆动幅度约 为 $137 \mathrm{~m}$, 相应岸顶不断崩退, 宽度约为 $195 \mathrm{~m} .2009$ 年以来河道管理部门对腊林洲滩岸采取削坡减载、抛石 镇脚等工程措施,基本控制了险情的发展,故右侧岸坡形态基本保持稳定.

3.1.2 下荆江典型断面崩岸过程 下荆江河道蜿蜒曲折, 主流摆动频繁, 河岸土体抗冲能力较差, 故多处河岸 出现不同程度的崩退现象. 三峡工程运用后, 下荆江北门口河段崩岸现象尤为突出, 崩退范围及速率较大, 主要是由于主流经过石首弯道顶点后持续顶冲北门口右岸 (图 $2 \mathrm{~b}$ ), 深泓下切 $3 \sim 6 \mathrm{~m}$. 此外, 北门口河段右 岸上层为粉质黏土 (约 $6 \mathrm{~m}$ 厚), 下层为沙土 (约 $20 \mathrm{~m}$ 厚), 抗冲性均较差, 容易发生崩岸现象. 图 $2 \mathrm{~b}$ 显示, 荆 98 断面右岸崩退强度较大, 2002-2018 年累计崩退宽度 $390 \mathrm{~m}$, 平均崩退速率为 $23 \mathrm{~m} / \mathrm{a}$. 虽然 2013 年以来 河道部门采取了一系列工程措施加固河岸, 大规模崩岸不再发生,但 2017-2020 年该河段已护岸段仍多次 发生崩岸.

\section{2 崩岸沿程分布及土体总量统计}

采用上述方法首先确定了荆江河段主要崩岸区域, 如图 5 所示. 崩岸区域沿程分布的总体特点为左岸 多于右岸, 下荆江崩岸多于上荆江. 图中大部分区域都已经实施了护岸工程, 仅下荆江部分凸岸边滩, 如向 家洲、八姓洲等仍在持续崩退.

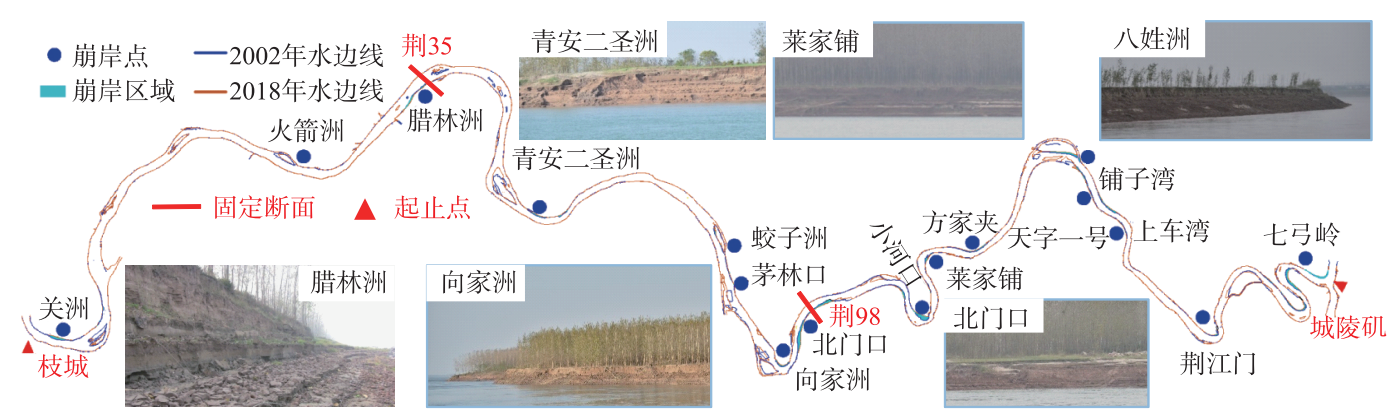

图 5 2002-2018 年荆江河段主要崩岸位置

Fig.5 Main zones of bank retreat in the Jingjiang reach from 2002 to 2018

表 1 统计了 2002-2018 年荆江段主要崩岸位置的累计崩退长度、宽度、面积、体积及土体总量. 荆江河 段累计岸线崩退长度约为 $123.7 \mathrm{~km}$, 占岸线总长度的 $17.8 \%$, 上、下荆江分别占 $30 \%$ 及 $70 \%$; 其中最大崩退 宽度及崩退面积均为北门口河段, 分别为 $490 \mathrm{~m} 、 2.2 \times 10^{6} \mathrm{~m}^{2}$. 近 $65 \%$ 的崩岸断面位于下荆江, 且主要发生在 主流顶冲或者深泓贴岸的区域, 由于石首、调关等弯道凹岸一侧多有护岸工程守护, 故凹岸一侧崩岸并不明 显, 而向家洲、来家铺、八姓洲等凸岸边滩近年来崩岸险情加剧, 且崩岸区域均集中在弯道上游一侧. $2002-$ 2018 年荆江段河岸累计崩退体积约为 2.0 亿 $\mathrm{m}^{3}$, 占同期该河段平滩河槽冲刷量 $\left(11.4\right.$ 亿 $\left.\mathrm{m}^{3}\right)$ 的 $17.5 \%$. 就分 河段而言, 枝江、沙市、郝穴、石首及监利河段崩岸体积占各自平滩河槽冲刷量的比例分别为 $3.5 \%$ 、 $4.3 \%$ 、 $8.8 \% 、 30.8 \%$ 及 $41.5 \%$, 表现为沿程递增趋势, 这也与下荆江崩岸多于上荆江的分布特点一致.

已有研究表明: 荆江段典型断面平滩河宽调整与前期水沙条件之间存在较好的幂函数关系 ${ }^{[21]}$. 此处选 取腊林洲、北门口两个典型崩岸位置, 进一步分析水沙条件变化对河岸崩退体积的影响, 其中腊林洲河段选 取了荆 34 与荆 36 之间的崩岸区域, 北门口河段则选取了荆 97 与荆 99 之间的崩岸区域. 分别统计了腊林 洲、北门口两个崩岸段在不同时段内的崩岸体积,如表 2 所示.

然后计算了上述两个崩岸段对应水文站的来水来沙因子. 三峡工程运用后, 荆江段水沙均集中在汛期 (5-10月)下泄, 且河床调整主要发生在汛期,故本研究主要考虑汛期来水来沙条件对崩岸的影响. 由于荆 江段含沙量较低, 来水来沙条件对崩岸的影响可由水流冲刷强度 $\bar{F}_{f}$ 来体现, 该参数包含了来流流量、含沙量 及历时, 可综合反映来水来沙条件对研究河段河床形态调整的影响. 采用式 (4) 分别计算了沙市站 $2002-$ 2011 年、监利站 $2002-2018$ 年各年份汛期平均水流冲刷强度 ${ }^{[7]}$ : 


$$
\bar{F}_{f}=\left(\bar{Q}_{f}^{2} / \bar{S}_{f}\right) / 10^{8}
$$

式中, $\bar{F}_{f}$ 为水流冲刷强度; $\bar{Q}_{f}$ 为汛期平均流量, $\mathrm{m}^{3} / \mathrm{s} ; \bar{S}_{f}$ 为汛期平均悬移质含沙量, $\mathrm{kg} / \mathrm{m}^{3}$.

表 1 2002-2018 年荆江河段崩岸土体总量分段统计结果

Tab.1 Statistics of the total sediment amount from bank retreat in the Jingjiang reach from 2002 to 2018

\begin{tabular}{|c|c|c|c|c|c|c|c|c|c|}
\hline 河段 & 序号 & 崩岸位置 & 岸别 & $\begin{array}{c}\text { 崩退 } \\
\text { 长度/ } \mathrm{km}\end{array}$ & $\begin{array}{c}\text { 崩退 } \\
\text { 宽度/m }\end{array}$ & $\begin{array}{l}\text { 崩退面积/ } \\
\left(\times 10^{4} \mathrm{~m}^{2}\right)\end{array}$ & $\begin{array}{c}\text { 河岸高度/ } \\
\mathrm{m}\end{array}$ & $\begin{array}{l}\text { 崩退体积/ } \\
\left(\times 10^{6} \mathrm{~m}^{3}\right)\end{array}$ & $\begin{array}{c}\text { 崩岸土量/ } \\
\left(\times 10^{6} \mathrm{t}\right)\end{array}$ \\
\hline \multirow[t]{3}{*}{ 枝江 } & 1 & 枝城 & 左岸 & 4.28 & 358.8 & 74.7 & 11 & 4.11 & 6.57 \\
\hline & 2 & 关洲 & 左岸 & 3.42 & 183.6 & 17.5 & 8.3 & 0.73 & 1.16 \\
\hline & 3 & 火箭洲 & 江心洲 & 3.69 & 130.3 & 61.7 & 10 & 3.08 & 4.93 \\
\hline 沙市 & 4 & 腊林州 & 右岸 & 5.8 & 192.6 & 58.4 & 20.63 & 12.06 & 15.31 \\
\hline \multirow[t]{4}{*}{ 郝穴 } & 5 & 突起洲 & 江心洲 & 2.1 & 52.6 & 10 & 12.84 & 1.28 & 1.79 \\
\hline & 6 & 耀民新堤 & 左岸 & 4.06 & 152.7 & 39.3 & 19.13 & 7.53 & 9.78 \\
\hline & 7 & 青安二圣洲 & 左岸 & 2.92 & 218.2 & 22.6 & 9.7 & 1.1 & 1.52 \\
\hline & 8 & 蛟子渊 & 江心洲 & 3.85 & 220.5 & 27.1 & 19.74 & 5.35 & 7.5 \\
\hline \multirow[t]{10}{*}{ 石首 } & 9 & 茅林口 & 左岸 & 4.9 & 85.6 & 27.6 & 26.1 & 7.2 & 10.37 \\
\hline & 10 & 倒口窑 & 左岸 & 2.1 & 83 & 9.5 & 12.3 & 1.17 & 1.72 \\
\hline & 11 & 向家洲 & 左/凸岸 & 3.1 & 208.9 & 38.4 & 21.28 & 8.18 & 9.81 \\
\hline & 12 & 北门口 & 右岸 & 10.7 & 490 & 217.5 & 17.04 & 37.07 & 50.78 \\
\hline & 13 & 塞妇夹 & 左/凸岸 & 4.29 & 234.5 & 41.3 & 4 & 0.83 & 1.16 \\
\hline & 14 & 小河口 & 左/凸岸 & 4.4 & 490 & 108.9 & 7.68 & 8.38 & 11.74 \\
\hline & 15 & & 左/凸岸 & 3.87 & 137 & 19.4 & 11.93 & 2.32 & 3.25 \\
\hline & 16 & 中洲子 & 左岸 & 1.82 & 104.2 & 11.8 & 12.1 & 1.43 & 2.05 \\
\hline & 17 & 来家铺 & 左/凸岸 & 2.81 & 328.9 & 30.7 & 9.5 & 2.92 & 4.09 \\
\hline & 18 & 方家夹 & 左岸 & 8.49 & 85 & 69.9 & 11.42 & 7.99 & 10.7 \\
\hline \multirow[t]{9}{*}{ 监利 } & 19 & 乌龟洲 & 江心洲 & 4.9 & 238.5 & 95 & 22 & 20.9 & 28.84 \\
\hline & 20 & 铺子弯 & 左岸 & 1.39 & 240 & 17.7 & 30.1 & 5.33 & 7.35 \\
\hline & 21 & 天字一号 & 右岸 & 7.19 & 81 & 61.6 & 14.49 & 8.92 & 12.31 \\
\hline & 22 & & 左岸 & 6.22 & 237 & 65.7 & 13.1 & 8.6 & 11.87 \\
\hline & 23 & 上车湾 & 右岸 & 3.54 & 123 & 25.1 & 16.6 & 2.08 & 2.88 \\
\hline & 24 & 荆江门 & 左/凸岸 & 3.63 & 168.3 & 26.8 & 11.9 & 3.19 & 4.4 \\
\hline & 25 & 八姓洲 & 左/凸岸 & 10.3 & 238.7 & 102.9 & 12.5 & 6.43 & 8.36 \\
\hline & 26 & 七娃洲 & 右/凸岸 & 5.57 & 333.1 & 112.3 & 15.1 & 16.95 & 23.74 \\
\hline & 27 & 观音洲 & 左/凸岸 & 4.4 & 239.1 & 49.4 & 27.49 & 13.59 & 18.34 \\
\hline
\end{tabular}

表 2 不同时段内腊林洲、北门口河段的崩岸体积 $\left(\times 10^{6} \mathrm{~m}^{3}\right)$

Tab.2 Volumes of bank retreat in the Lalinzhou and Beimenkou sub-reaches during different periods $\left(\times 10^{6} \mathrm{~m}^{3}\right)$

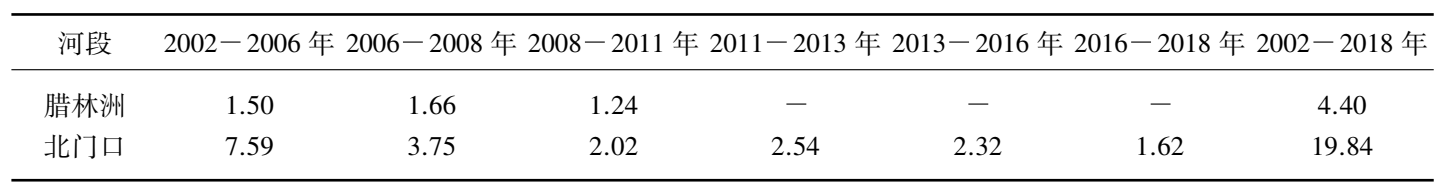

最后点绘腊林洲与北门口河段累计崩岸体积与累计水流冲刷强度之间的关系曲线, 如图 6 所示. 结果 表明, 三峡工程运用后, 荆江腊林洲和北门口河段累计崩岸体积与累计水流冲刷强度呈较好的幕函数关系, 决定系数 $\left(R^{2}\right)$ 分别为 0.95 和 0.97 . 累计水流冲刷强度指相应崩岸时段每年汛期水流冲刷强度之和, 用于体 现水流冲刷河岸的累积作用. 由此可见, 来水来沙条件很大程度上决定局部河段的崩岸体积. 

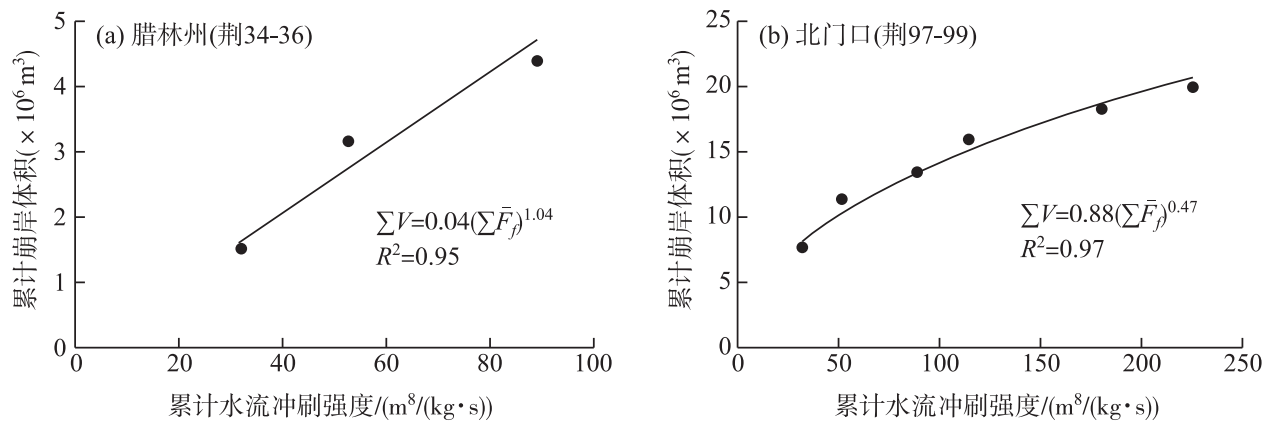

图 6 不同河段累计崩岸体积与累计水流冲刷强度之间的关系:腊林洲 (a); 北门口 (b)

Fig. 6 Empirical relationships between the cumulative bank erosion volume and cumulative fluvial erosion intensity in the sub-reaches of Lalinzhou (a) and Beimenkou (b)

\section{4 崩岸对荆江段河床调整的影响}

崩岸不仅在平面上表现为岸线崩退, 导致岸线资源受损, 同时也会影响河床形态调整. 此处分析河岸崩 退对河床调整的具体影响,包括崩岸土体对沿程泥沙输移与崩岸对断面形态调整的影响.

\section{1 崩岸土体对输沙量的贡献}

崩岸土体是河道输沙的重要来源之一, 河岸土体崩塌后, 土体中的细颗粒泥沙被水流挟带直接参与河 道输沙, 而大块或整块的土体则堆落在坡脚位置, 后期逐步被水流分解进而参与河道输沙, 尤其是在汛期流 量较大的时段 ${ }^{[20]}$. 已有研究表明,崩岸土体对河道输沙量的贡献率可达 $5 \% \sim 80 \%{ }^{[22]}$. 表 1 统计数据表明, 2002-2018 年荆江河段崩岸土体产生的泥沙总量约为 2.72 亿 $\mathrm{t}$, 其中枝城一监利河段为 1.67 亿 $\mathrm{t}$, 同期枝城 站、监利站累计输沙量分别为 9.42 亿和 13.10 亿 $\mathrm{t}$, 荆江三口总分沙量为 1.76 亿 $\mathrm{t}$ (图 7). 因此枝城一监利河 段沿程河床补给泥沙量约为 5.44 亿 $\mathrm{t}$, 包括床面泥沙补给和崩岸土体补给, 其中细沙 (粒径小于 $0.125 \mathrm{~mm}$ ) 和粗沙 (粒径大于 $0.125 \mathrm{~mm}$ ) 补给量分别为 2.52 亿和 2.92 亿 $\mathrm{t}$. 若崩岸土体均参与输沙, 则占沿程泥沙补给 总量的 30.7\% . 如考虑临底悬沙漏测等情况, 计算误差约为 5\% 10\%. 根据收集的河岸土体特性资料分析, 荆江河段二元河岸土体上部黏土层的粒径基本小于 $0.1 \mathrm{~mm}$, 属于细沙, 河岸下部沙土层中细沙比例约为 $50 \% \sim 85 \%$, 故河岸土体主要为细沙. 因此崩岸过程很大程度上为坝下游河道细沙的沿程恢复做出了重要 贡献.

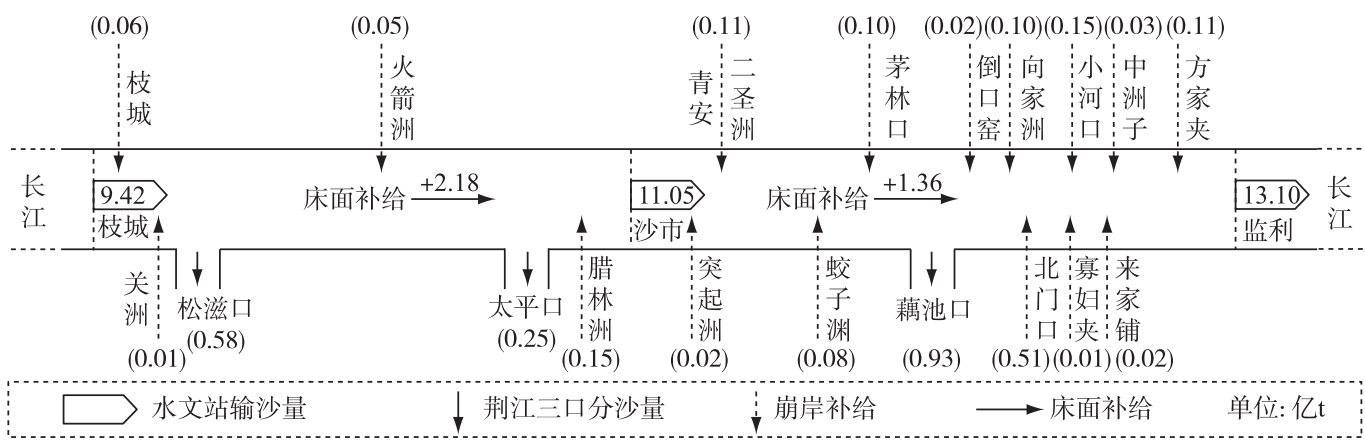

图 $72002-2018$ 年枝城一监利河段河床及河岸泥沙累计补给量

Fig.7 Total amounts of the sediment supplied from the bed and banks in the Zhicheng-Jianli reach from 2002 to 2018 


\section{2 崩岸对断面形态调整的影响}

河岸持续崩退对断面形态调整有显著影响,一方面会导致断面横向展宽,另一方面会影响床面的冲淤 部位. 2002-2018 年荆江段主要崩岸区域的最大崩岸宽度为 53 490 m, 可见这些断面存在明显的横向展宽 (表 1). 已有研究表明: 主流顶冲导致河岸崩退, 崩塌土块堆积在近岸坡脚, 分散水流并形成回流区淘刷河 岸, 崩岸范围向下游延伸, 一定程度上减缓了近岸床面的下切速率 ${ }^{[23]}$. 由于部分崩岸区域靠近城镇, 岸线守 护具有重要意义, 沿江河道或航道管理部门修建了大规模的河势控制及护岸工程, 致使近岸坡脚不再冲刷 内靠, 延缓或者阻止了大规模崩岸的发生, 水流转而冲刷河床其他部位, 断面形态调整趋势也发生改变.

三峡工程运用后腊林洲右岸明显崩退, 荆 34-36 断面形态调整以展宽为主;2010 年修建护岸工程后断 面形态调整以冲深下切为主 (图 8a). 北门口河段荆 97-99 断面形态调整也表现出类似特点, 2002 以来右岸 持续崩退, 断面形态调整以横向展宽为主, 2013 年护岸工程修建后, 平滩河槽变形主要表现为冲深下切 (图 8b). 图 8 也给出了上述两个局部河段 2002-2018 年平滩河槽宽深比均值与水流冲刷强度的经验关系: 可 见护岸工程修建前, 由于腊林洲及北门口右岸均持续崩退, 平滩河宽持续增大, 而平滩水深变化不大, 故平 滩河槽宽深比呈增大趋势, 河槽趋于宽浅; 护岸工程修建后, 由于平滩河宽基本不变, 而平滩水深均随着水 流冲刷强度的增加而显著增加, 此时平滩河槽宽深比明显减小, 腊林洲及北门口河段相应宽深比分别从 $100 、 142$ 减小至 $82 、 136$, 河床变形主要表现为冲刷下切,趋于窄深. 上述分析表明,两个崩岸区域在河岸崩 退以及不崩退阶段表现出的河床调整模式略有不同. 在荆江段河床整体冲刷下切的趋势下,河道崩岸对断 面形态调整的影响主要表现为: 河岸崩退可以在一定程度上减缓河床冲深下切的速度, 从而改变断面形态 的调整模式.
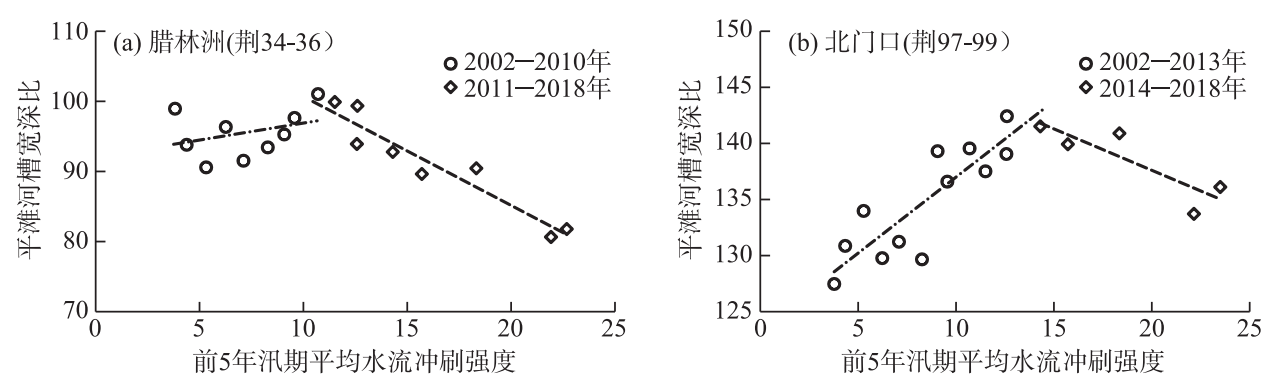

图 8 不同河段护岸工程修建前后平滩河槽形态变化与水流冲刷强度的关系:腊林洲 ( a ) ; 北门口 (b)

Fig.8 Relationships between temporal changes of bankfull channel geometry and previous five-year average fluvial erosion intensity before and after the construction of bank-revetment works in the sub-reaches of Lalinzhou (a) and Beimenkou (b)

\section{5 结论}

1) 采用长程河道地形、固定断面地形资料确定了荆江段主要崩岸区域, 估算了崩岸土体体积及泥沙总 量. 计算结果表明: 2002-2018 年荆江段崩岸区域分布总体特点为下荆江多于上荆江, 左岸多于右岸; 岸线 累计崩退长度为 $123.7 \mathrm{~km}$, 占总岸线长度的 $17.8 \%$, 上、下荆江分别占 $30 \% 、 70 \%$; 累计河岸崩退体积约为 2.0 亿 $\mathrm{m}^{3}$, 占该河段同期河道冲刷量的 $17.5 \%$.

2) 建立了腊林洲与北门口河段累计崩岸体积与累计水流冲刷强度的经验关系, 结果表明: 两者呈较好 的幂函数关系, $R^{2}$ 分别为 $0.95 、 0.97$. 因此来水来沙条件同样能影响局部河段河岸崩退的土体体积.

3) 定量分析了河岸崩退对荆江段河床调整的影响: 2002-2018 年该河段崩岸土体的泥沙总量为 2.72 亿 $\mathrm{t}$, 其中枝城一监利河段崩岸土体总量为 1.67 亿 $\mathrm{t}$, 约占该河段沿程泥沙补给总量的 $30.7 \%$, 因此崩岸对沿 程河道输沙有重要贡献; 腊林洲及北门口局部河段的断面形态调整表明, 崩岸通常导致断面形态趋于宽浅, 而护岸工程修建后则明显趋于窄深, 说明崩岸在一定程度上可以减缓河床冲刷下切速度并改变断面形态的 调整模式. 


\section{6 参考文献}

[ 1 ] Williams GP, Wolman MG eds. Downstream effects of dams on alluvial rivers, professional Paper 1286. Washington DC: US Geological Survey, 1984.

[ 2 ] Petts GE, Gurnell AM. Dams and geomorphology: Research progress and future directions. Geomorphology, 2005, 71(1/ 2) : 27-47. DOI: 10.1016/j.geomorph.2004.02.015.

[ 3 ] Xia JQ, Zong QL eds. Mechanism and numerical simulation of bank erosion in Jingjiang Reach of Yangtze River. Beijing: Science Press, 2015. [夏军强, 宗全利. 长江荆江段崩岸机理及其数值模拟. 北京: 科学出版社, 2015]

[ 4 ] Best J. Anthropogenic stresses on the world's big rivers. Nature Geoscience, 2019, 12(1) : 7-21. DOI: 10.1038/s41561018-0262-x.

[ 5 ] Hu CH, Zhang SH. Discussion on development and protection strategy of Yangtze River. Yangtze River, 2020, 51(1): 1 5. [胡春宏, 张双虎. 论长江开发与保护策略. 人民长江, 2020, 51(1): 1-5.]

[ 6 ] Zhang XN, Jia DD, Chen CY. The spatial and temporal distribution characteristic of bank collapses in the middle and lower reaches of the Yangtze River. Journal of Basic Science and Engineering, 2021, 29(1): 55-63. [张幸农, 假冬冬, 陈 长英. 长江中下游崩岸时空分布特征与规律. 应用基础与工程科学学报, 2021, 29(1): 55-63.]

[ 7 ] Xia JQ, Lin FF, Zhou MR et al. Bank retreat processes and characteristics in the Jingjiang Reach after the Three Gorges Project operation. Advances in Water Science, 2017, 28(4) : 543-552. [夏军强, 林芬芬, 周美蓉等. 三峡工程运用后 荆江段崩岸过程及特点. 水科学进展, 2017, 28(4): 543-552.]

[ 8 ] Payne C, Panda S, Prakash A. Remote sensing of river erosion on the Colville River, North Slope Alaska. Remote Sensing, 2018, 10(3) : 397. DOI: 10.3390/rs10030397.

[ 9 ] Xu QX. Study of sediment deposition and erosion patterns in the middle and downstream Changjiang mainstream after impoundment of TGR. Journal of Hydroelectric Engineering, 2013, 32(2) : 146-154. [许全喜. 三峡工程蓄水运用前后长 江中下游干流河道冲淤规律研究. 水力发电学报, 2013, 32(2) : 146-154.]

[10] Xu JX, Shi CX. Bank erosion in the braided reach downstream of theDanjiangkou Reservoir on the Hanjiang River and its significance in the channel adjustment. Chinese Science Bulletin, 1995, 40(18) : 1689-1692. [许昫心, 师长兴. 汉江丹 江口水库下游游荡段河岸侵蚀及其在河床调整中的意义. 科学通报, 1995, 40(18) : 1689-1692.]

[11] Barker R, Dixon L, Hooke J. Use of terrestrial photogrammetry for monitoring and measuring bank erosion. Earth Surface Processes and Landforms, 1997, 22(13): 1217-1227.

[12] Williams F, Moore P, Isenhart T et al. Automated measurement of eroding streambank volume from high-resolution aerial imagery and terrain analysis. Geomorphology, 2020, 367: 107313. DOI: 10.1016/j.geomorph.2020.107313.

[13] Azuma. Studies of high-resolution morphodynamics with special reference to river bank erosion. Annuals of Disaster Prevention Research Institution, Kyoto University, 2007, 50( C) : 199-209.

[14] Leyland J, Hackney CR, Darby SE et al. Extreme flood-driven fluvial bank erosion and sediment loads: Direct process measurements using integrated Mobile Laser Scanning (MLS) and hydro-acoustic techniques. Earth Surface Processes and Landforms, 2017, 42(2) : 334-346. DOI: 10.1002/esp.4078.

[15] Zhao YA, Zhou WH, Fei XJ et al eds. Channel evolution principles in the lower Yellow River. Zhengzhou: Yellow River Conservancy Press, 1998. [赵业安, 周文浩, 费祥俊等. 黄河下游河道演变基本规律. 郑州: 黄河水利出版 社, 1998.]

[16] Xia JQ, Li J, Carling PA et al. Dynamic adjustments in bankfull width of a braided reach. Proceedings of the Institution of Civil Engineers-Water Management, 2019, 172(4) : 207-216. DOI: 10.1680/jwama.17.00043.

[17] Shin YH, Julien PY. Changes in hydraulic geometry of the Hwang River below the Hapcheon Re-regulation Dam, South Korea. International Journal of River Basin Management, 2010, 8(2) : 139-150. DOI: 10.1080/15715121003651252.

[18] Spiekermann R, Betts H, Dymond J et al. Volumetric measurement of river bank erosion from sequential historical aerial photography. Geomorphology, 2017, 296: 193-208. DOI: 10.1016/j.geomorph.2017.08.047.

[19] Xia JQ, Zong QL, Deng SS et al. Seasonal variations in composite riverbank stability in the Lower Jingjiang Reach, China. Journal of Hydrology, 2014, 519: 3664-3673. DOI: 10.1016/j.jhydrol.2014.10.061.

[20] Zhang XL, Weng ZP, Liu ZJ et al. Random section extraction method and terrain simulation of topographic map of the 
Yangtze River. Yangtze River, 2006, 37 (8) : 29-30, 37. [张夏林, 翁正平, 刘志军等. 长江河道地形图任意断面提 取方法及地形模拟. 人民长江, 2006, 37(8): 29-30, 37.]

[21] Xia JQ, Deng SS, Zhou MR et al. Geomorphic response of the Jingijiang Reach to the Three Gorges Project operation. Earth Surface Processes and Landforms, 2017, 42(6) : 866-876. DOI: 10.1002/esp.4043.

[22] Bull LJ. Magnitude and variation in the contribution of bank erosion to the suspended sediment load of the River Severn, UK. Earth Surface Processes and Landforms, 1997, 22(12): 1109-1123.

[23] Hackney C, Best J, Leyland J et al. Modulation of outer bank erosion by slump blocks: Disentangling the protective and destructive role of failed material on the three-dimensional flow structure. Geophysical Research Letters, 2015, 42(24) : 10663-10670. DOI: 10.1002/2015gl066481. 